Chapter Title: CHINESE RELIGION, MARKET SOCIETY AND THE STATE

Chapter Author(s): Jack Barbalet

Book Title: Religion and the State

Book Subtitle: A Comparative Sociology

Book Editor(s): Jack Barbalet, Adam Possamai, Bryan S. Turner

Published by: Anthem Press. (2011)

Stable URL: http://www.jstor.org/stable/j.ctt1wnOr14.14

JSTOR is a not-for-profit service that helps scholars, researchers, and students discover, use, and build upon a wide range of content in a trusted digital archive. We use information technology and tools to increase productivity and facilitate new forms of scholarship. For more information about JSTOR, please contact support@jstor.org.

Your use of the JSTOR archive indicates your acceptance of the Terms \& Conditions of Use, available at http://about.jstor.org/terms

This book is licensed under a Creative Commons Attribution 4.0 International. To view a copy of this license, visit http://creativecommons.org/licenses/by/4.0/. Funding is provided by Knowledge Unlatched. 


\title{
Religion and the State
}

\section{A Comparative Sociology}

\author{
Edited by \\ Jack Barbalet, Adam Possamai \\ and Bryan S. Turner
}

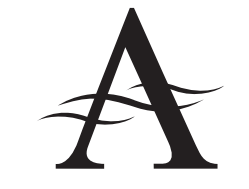

ANTHEM PRESS

LONDON $\cdot$ NEW YORK $\cdot$ DELHI 
Anthem Press

An imprint of Wimbledon Publishing Company

wrere.anthempress.com

This edition first published in UK and USA 2011

by ANTHEM PRESS

75-76 Blackfriars Road, London SE1 8HA, UK

or PO Box 9779, London SW19 7ZG, UK

and

244 Madison Ave. \#116, New York, NY 10016, USA

(C) 2011 Jack Barbalet, Adam Possamai and Bryan S. Turner editorial matter and selection;

individual chapters (C) individual contributors

The moral right of the authors has been asserted.

Front cover image (C) 2011 iStockphoto.com/Cosmonaut

All rights reserved. Without limiting the rights under copyright reserved above, no part of this publication may be reproduced, stored or introduced into

a retrieval system, or transmitted, in any form or by any means

(electronic, mechanical, photocopying, recording or otherwise),

without the prior written permission of both the copyright

owner and the above publisher of this book.

British Library Cataloguing-in-Publication Data

A catalogue record for this book is available from the British Library.

Library of Congress Cataloging-in-Publication Data

Religion and the state : a comparative sociology / edited by Jack Barbalet, Adam

Possamai, Bryan S. Turner.

p. cm.

Proceedings of a workshop held July 17-18, 2009 at the University of Western Sydney,

Parramatta Campus.

Includes bibliographical references and index.

ISBN 978-0-85728-798-4 (hardback : alk. paper)

1. Religion and state-Congresses. I. Barbalet, J. M., 1946- II. Possamai, Adam.

III. Turner, Bryan S.

BL65.S8R4455 2011

$322^{\prime} \cdot 1-\mathrm{dc} 23$

2011039325

ISBN-13: 9780857287984 (Hbk)

ISBN-10: 0857287982 (Hbk)

This title is also available as an eBook. 


\section{TABLE OF GONTENTS}

Acknowledgements vii

Notes on Contributors $\quad$ ix

List of Tables and Figures xiii

Introduction States, Consumption and Managing Religions $\quad 1$

Bryan S. Turner, Adam Possamai and Fack Barbalet

\section{Part I: From Deprivitization to Securitization}

Chapter 1 Religion in Liberal and Authoritarian States

Bryan S. Turner

Chapter 2 Religion in Prisons and in Partnership with the State Fames A. Beckford

Chapter 3 The Secularization Thesis and the Secular State:

Reflections with Special Attention to Debates

in Australia

Stephen Chavura

Chapter 4 Secularism, Religion and the Status Quo

Gal Levy

Chapter 5 Managing China's Muslim Minorities: Migration,

Labor and the Rise of Ethnoreligious

Consciousness among Uyghurs in Urban Xinjiang

Reza Hasmath

Chapter 6 The Tension Between State and Religion in American Foreign Policy

Douglas Porpora

Chapter 7 Church, State and Society in Post-communist Europe

Siniša Zrinščak 


\section{Part II: From Pietism to Consumerism}

Chapter 8 Chinese Religion, Market Society and the State Fack Barbalet

Chapter 9 Hindu Normalization, Nationalism and Consumer Mobilization

Arathi Sriprakash and Adam Possamai

Chapter 10 Clash of Secularity and Religiosity: The Staging of Secularism and Islam through the Icons of Atatürk and the Veil in Turkey

Meyda Yeğenoğlu

Chapter 11 Gramsci, Jediism, the Standardization of Popular Religion and the State

Adam Possamai

\section{Part III: Concluding Comments}

Chapter 12 Concerning the Current Recompositions of Religion and of Politics

Patrick Michel

Chapter 13 Public Religions and the State: A Comparative

Perspective

Jack Barbalet, Adam Possamai and Bryan S. Turner 


\title{
Chapter 8
}

\section{CHINESE RELIGION, MARKET SOCIETY AND THE STATE}

\author{
Jack Barbalet
}

Hong Kong Baptist University

\section{Introduction}

The familiar discussion of the nexus between religion and economy has emblematic representation in Max Weber's classic account of the elective affinity between Calvinism and the spirit of modern capitalism (Weber, 1991). Weber's demonstration of the supportive role of religious belief for capitalistic development is reversed, however, in his treatment of the history of China in which it is argued that Confucianism and Daoism had a compelling restraining impact on economic rationalization (Weber, 1964). This reversal has an additional dimension, insofar as an unintended consequence of the development of an expanding market economy and concomitant industrialization in China since the Deng Xiaoping reforms in 1978 has been to provide a space for religious expression unprecedented since the advent of the communist regime in 1949, and possibly even before this time given the predominantly negative policies toward religion by the state during the republican period from 1912. Indeed, since the onset of the reform period in the 1980s there has been not only more evidence of religious commitment and activity in both rural and urban areas but also changes in the nature of individual religions and in the numbers of religious adherents.

The most striking religious changes in the People's Republic of China (PRC) over the last 25 or so years have been twofold. The first consists of the reforms in both Buddhism and Daoism, especially in outreach and growth in the numbers of temples, priests and adherents or participants, which have largely been state sponsored or supported. The second is that the Christian presence in China and its diversity has significantly expanded. 
However, apart from the permissive and regulatory role of the state in each of these developments, these trends do not point in the same direction. A good deal has been written about the growth of Christianity in China, but it is possibly the least understood of these changes. Much of the Christian expansion is in the PRC's rural sector (Huang and Yang, 2005) and while the Protestantism that is currently growing in major cities may be seen by some of its adherents as supportive, even expressive of a free market economy, a more comprehensive profile of Chinese Christianity suggests a tendency to social and economic conservatism.

It will be shown in the discussion below that a revival of Buddhism and Daoism, which on the surface appears even less remotely connected with the promotion of market economy in the PRC than Christianity, is an important mechanism in the provision of investment required for economic development in China. This is because the growth of Buddhism and Daoism both attract and are fueled by overseas Chinese contributors to the mainland economy. The capacity of the overseas Chinese to invest in the PRC derives from their success in business, commerce and finance in East and Southeast Asia. This development raises doubts concerning Weber's account of the negative impact of Confucian and Daoist orientations for capitalistic activity. This is because the overseas Chinese population that has been economically successful is generally endowed with the traditional Confucian and Daoist outlook Weber saw as responsible for inhibiting the development of capitalistic orientations and practices. Both of these aspects of the relationship between Chinese capitalism and Chinese religion shall be discussed in what follows. While these issues arise through the historical recentness of China's embrace of a market economy, it should not be assumed that its principles are entirely foreign to China, a matter raised in the following section.

\section{Laissez-Faire and Daoism: Wu Wei}

Joseph Needham, the distinguished author of the multivolumed Science and Civilization in China (1954-2004), famously demonstrated that practically every significant invention in human history originated in China: not only gunpowder and printing but also alcohol, ball bearings, the magnetic compass, paper, toilet paper, the stirrup, the toothbrush and so on. Not only physical but also social technologies can be sourced to Chinese origins. While no Needhamlike figure has yet written Social Science and Civilization in China, it can be shown that the concept of a laissez-faire instrument of Chinese political economy, for instance, was not only clearly articulated 100 years before Christ but also that the Chinese doctrine of laissez-faire was self-consciously borrowed by the eighteenth-century French economist, François Quesnay, in development 
of his physiocratic theory (Gerlach, 2005; Hudson, 1961: 322-6; Reichwein, 1968: 99-110). Anticipating Adam Smith by 1,850 years, the great Han Dynasty historian Sima Qian wrote:

There must be farmers to produce food, men to extract the wealth of mountains and marshes, artisans to produce these things and merchants to circulate them. There is no need to wait for government orders: each man will play his part, doing his best to get what he desires... When all work willingly at their trades, just as water flows ceaselessly downhill day and night, things will appear unsought and people will produce them without being asked. For clearly this accords with the Way and is in keeping with nature. (Chien, 1979: 411)

It is evident within this passage that the conceptual root of the economic notion of laissez-faire reported here, directed against feudal practices of interference, is Daoist.

The water metaphor contained in the passage above is characteristic of the principal Daoist texts dating from the third century BC, namely the Daode jing (sometimes referred to as the Laozi after its putative author) and the Zhuangzi. But more important in demonstrating the Daoist nature of Sima Qian's discussion is the way in which the passage above expresses the key Daoist principle of wu wei. Wu wei can be translated as "doing less" or "noncoercive action." The passage above from Sima Qian paraphrases sections of the Daode jing in showing that the performance of trade and the division of labor occur in the absence of government engagement which itself indicates that "this accords with the Way [or Dao]" and in doing so is consonant with nature:

It is simply in doing things non-coercively (wuwei) that everything is governed properly... do things non-coercively (wuwei) and the common people will develop along their own lines. (Ames and Hall, 2003: $82,166)$

The point of these passages from the Laozi - and also those from Sima Qian is that a state that practices wu wei does less, yet everything is accomplished in accordance with the needs of the state.

It is not necessary, of course, to go back to the Han Dynasty to locate evidence of pre-1978 Chinese inclinations to laissez-faire or market capitalism. Well before China embraced a market economy in the 1980s, southern Chinese migrants in East and Southeast Asia from the mid-nineteenth century and throughout the twentieth century were successfully engaged in capitalist activities. It will be shown below that the capitalism of the overseas Chinese, 
ironically, has been an instrumental factor in the more recent development of a capital market in the PRC, with the help of the Chinese state. It will also be shown that Daoism continues to play a role in Chinese capitalist success, as it did in the formulation of laissez-faire doctrine during the Han Dynasty. It might be mentioned parenthetically that in the PRC today, there is continuing application of Daoist principles to analysis of economic development. Since 2000 there have appeared in Chinese social science and Party journals a number of articles in which Daoist concepts, especially wu wei and related notions, are applied to understanding the development and operation of China's market economy (see Barbalet, 2011). Given the continuing importance of Daoism to Chinese self-understanding of markets and to an account of the Chinese economy, it is necessary to mention a number of issues relating to the distinctive features of Chinese religion.

\section{Chinese Religion}

It is often noted in indicating the complexity of Chinese traditions that Daoism, for instance, is both a religion and philosophy. We shall return to this distinction below. Before doing so, however, it is important to understand that the concepts of both religion and philosophy were until recently unknown to Chinese language and culture. The current Chinese term for religion, jiao, is an abbreviation of a word imported at the beginning of the twentieth century from Japanese and sinicized as zong jiao. An earlier Chinese term, san jiao, used from the ninth century to refer to Buddhism, Daoism and Confucianism collectively, means not "three religions" but "three teachings" (Sun, 2005: 232-3; see also Ashiwa and Wank, 2009: 9). The Chinese term for philosophy, zhexue, is also a Japanese invention created at the end of the nineteenth century by combining the Chinese characters for wisdom (zhe) and study (xue). Before this innovation there was instead only study of the canon or great books (jing xue) and the traditions of the masters (zi xue) (Yijie, 2007: 33-4). Daoism, then, offers a way of seeing the world as a means of being in it - it is one teaching (yi jiao) and the texts of Daoism, for instance the Laozi and Zhuangzi and their purported authors, can be objects of study (jing xue). Daoism as a "religion" and "philosophy" in this sense, then, refers only to the fact that it is a pedagogic practice and that the practice is associated with books that can be the objects of contemplation, reflection and commentary.

At the present time in the PRC, Daoism may increasingly appear to be like a religion in the Western sense because it is increasingly transformed by regulation, training, professionalization and outreach that derive from modern political requirements and cultural transformations (Yang, 2005; Dean, 2009). The philological asides of the previous paragraph help make 
sense of the commonplace observation that the notion of "Chinese religion" presents certain problems of specification and classification because an understanding of religion in the Western sense - of focus on a deity, a sacred-profane dichotomy, transcendence and so on - is not readily located in the Chinese cases. The asides also lead us to other aspects of Chinese tradition in addition to the modernizing forces to which Daoism and Buddhism are today subjected, which are themselves suggestive of certain limits on how far these "teachings" can go in becoming religions in the Western sense. For the sake of making the argument it is necessary, though, in spite of what has been written above, to refer to Chinese "religion" in order to more clearly indicate the nature and context of these cultural practices and patterns of thought.

In an important sense, Chinese religion and European religion can be regarded as practically opposites. Chinese religion has always been polytheistic and nonexclusive, whereas European religion is monotheistic and exclusive. In China, priests and what would pass in the Western sense as clergy have traditionally been small in number and poorly organized (Yang, 1961: 307-27). Unlike Western religion, Chinese religion has historically failed to provide social services or education (Yang, 1961: 335-9), although this is subject to modest change today (Yang and Wei, 2005: 69-70; Lang, Chan and Ragvald, 2005: 163). Chinese religious nonexclusivity and therefore the absence of exclusive patronage has contributed to the organizational weakness of Chinese religion, whereas Western religious exclusivity has led to a disciplined clergy and wellorganized laity. Marcel Granet summarizes the Chinese case:

The Chinese are not divided up into followers of one or another of the three faiths; in circumstances fixed by tradition they appeal at the same time to Buddhist or Taoist priests, even to [Confucian] literati or officials. Not only do they never submit to a dogmatic parti pris, but when they have recourse to specialists, they do not show towards them the veneration of the sort due to members of a clergy. (Granet, 1975: 144)

A final striking difference to be mentioned here between Chinese religion and European religion is their relationship with the political state. The Chinese state - imperial and republican as well as communist - has always constituted a powerful force over and against organized (perhaps it is more accurate to say in light of the above remarks, disorganized) religion, and the Chinese tradition is one of political dominance over and control of religion (Yang, 1961: 180-217). While there have been periods of state patronage, the typical orientation of the state towards religion since the early Ming Dynasty in the fourteenth century has been a mix of regulation and prohibition (Brook, 2009). The early 
history of Christianity, on the other hand, prior to the Reformation, was of a continentally organized church empire against small and divided secular governments. Against this background, the politically instrumental utility of national Protestant churches to European states provided reform churches with a power which they may still call upon and exercise in defense of their own independence.

The image of the weakness of Chinese religion created in the preceding paragraph relates to its organizational capacities, but a further characteristic of Chinese religion that requires special consideration is its enduring cultural presence and force. Before pursuing this theme, however, it is necessary to say something about Confucianism, which has so far been ignored. Western commentators have frequently regarded Confucianism as a religion even though the absence of religious consciousness with regard to it on the part of adherents suggests that the appellation is misplaced. Indeed, the failed attempt to establish a Confucian religion during the republican period for largely political reasons (Yang, 1961:355-8; Sun, 2005: 234-6) suggests the artificiality and misleading nature of the idea that Confucianism is a religion in any meaningful sense. This is not to say that there are not elements of Confucianism that arguably possess religious qualities, such as self-cultivation productive of social order or harmony expressed in a clear ethical code through a positive orientation to ritual practices (see Yang, 1961: 244-77). Perhaps more important than the observer ascribed as opposed to adherent experienced religious characteristics of Confucianism is its long-standing and complex relationship, since the ninth century, of opposition and creative engagement with both Buddhism and Daoism, that has seen each contest, adapt to and mimic aspects of the others over a long period of Chinese history.

The last point above can be taken to imply that Confucianism, Buddhism and Daoism have changed through their mutual interactions. Of course, such interactions are not the only sources of change, but they do suggest that not one of these three traditions can be regarded as entirely unitary entities when considered over historical time. The point has been made that Confucianism, for instance, is "not one philosophy, but many" and that while "Neo-Confucianism, a movement dating from the late T'ang... is not only significantly different from what went before, (it is) very far from a unified philosophy itself" (Nivison, 1959: 4). Daoism even more than Confucianism can be seen as a single label that covers a number of quite different movements and purposes. In a seminal paper that has become the source of much controversy, Herrlee Creel has shown that Daoism is in effect three, not one set of principles and practices (Creel, 1977).

Creel distinguishes "contemplative" and "purposive" Daoism associated respectively with the Zhuangzi and the Daodejing, one cultivating an understanding 
of the Dao or Way to achieve inner strength and the other to achieve a means of power and kingly council (Creel, 1977: 4-6). At an historically later period, a set of practices and doctrines were consolidated into a movement that went on to manifest variant and divergent forms, but with the continuing purpose of attaining immortality for its practitioners, which amalgamated elements of folk immortality cults, Buddhist organizational forms and the Daoist name (Creel, 1977: 7-8). Creel names this third type of Daoism not "religious" Daoism but Hsien Daoism - hsien being an immortal - because the "immortality in question was a perpetuation of the physical body" (Creel, 1977: 7). The means used to achieve everlasting life or at least extraordinary longevity included drugs and alchemic practices, breath control and gymnastics, dietary management and macrobiotics, moral (Confucian) virtue, sexual techniques, magical rites and charms and talismans all of which are opposed or ridiculed in the Zhuangzi and the Daode jing (Creel, 1977: 8-9). The important point, which it is not Creel's purpose to make, is that irrespective of their logical and historical relationship the anarchistic contemplative Daoism which promotes inner self-cultivation, the instrumentally purposive Daoism which navigates social and political power and the curative and restorative Hsien Daoism which extends and improves life and living have all been contemporaneously available for nearly two thousand years within the Chinese cultural framework of doctrinal and practical nonexclusivity.

The characteristic organizational weakness of Chinese religion, for want of a better term, belies its enduring cultural presence and power. The real strength of Chinese religion arguably derives from what C. K. Yang, following Durkheim, calls its "diffused" form (Yang, 1961: 296-300). A religion is diffused when its outlook and concepts are insinuated in and dispersed through secular social institutions and in that sense are a part of those institutions. Yang reserves this concept for his discussion of folk religions and especially ancestor worship, neither of which have the benefit of organized sanction or rationale. But Confucianism, Buddhism and Daoism (in each of its three forms) have a continuing diffused, that is noninstitutional representation in many aspects of Chinese life and culture. In the domain of self-cultivation, for instance, Confucian and Daoist concepts are essential for understanding Chinese practices; in business, military strategy and environmental policy purposive Daoist concepts predominate; in medical and health matters and in the rhythm of mundane life, Hsien Daoist rituals prevail; and so on. These and related traditions are diffused through Chinese culture and many of their key concepts are given representation in the Chinese language itself. The significance of the cognitive framework of Chinese religions will be taken up below. 


\section{State Management of Religion and the Market Economy in China Since 1978}

Twenty-first century China can justifiably be seen as a site of religious effervescence. In addition to the appreciable rise in Christianity there have also emerged new religious movements, the best known being Falun Gong (Ownby, 2004). Alongside these changes and arguably more important for an understanding of current political and economic developments in the PRC is a revival of Buddhism and Daoism, a significant aspect of which includes the rebuilding of damaged or destroyed temples. The activity of temple rebuilding is state sponsored, privately funded and quite central to the ongoing expansion of economic development.

As a large proportion of temples in China were traditionally communal property, it was not unusual even in imperial times for them to be put to nonreligious use as the need arose, a process hastened with the formation of the republic in 1912 and secular modernization that continued after 1949 with the establishment of the PRC (see Yang, 1961: 326, 368). It has been estimated that by the end of the republican period half of China's local temples had been destroyed, and that during the period of the Cultural Revolution (1966-76) tens of thousands of the remaining Buddhist, Daoist and other temples were destroyed as part of active antireligious campaigns (Goossaert, 2003). In contrast to the events of the 1960s and 1970s in the PRC, there has emerged from the early 1980s a new tolerance toward religion. The third constitution of the PRC promulgated in 1978 introduced limited guarantees of religious freedom. Such freedoms have been extended in Article 36 of the subsequent 1982 constitution, which remains current. Article 36 indicates a move from state prohibition to state regulation of religion; it declares that while religions are not to "engage in activities that disrupt public order, impair the health of citizens or interfere with the educational system of the state" the state shall "protect normal religious activities." What these normal activities might be are not specified except in the negative case as indicated. This qualified relaxation of overall hostility towards religion from the late 1970s has accelerated to a positive acceptance of aspects of religion in particular religions so that by the mid-1990s there have been permitted, even encouraged, large-scale and vigorous efforts at restoration and refurbishment of temples and other religious buildings destroyed during the Cultural Revolution. By 1996, for instance, 1,722 Daoist temples had been restored and opened (Dean, 2009: 193).

The new qualified acceptance of religion in the PRC is an aspect of a broader liberalization that has accompanied China's incorporation into the international capitalist economy and its entry on to the world political stage. 
While state suppression of religious movements such as Falun Gong (Tong, 2009) and the smaller Dongfang Shandian (Eastern Lightning) continues in the PRC (Dunn, 2009), the constitutional guarantees of freedom of religious belief and practice are given meaningful expression for Buddhist, Daoist, Catholic, Protestant and Islamic organizations that are affiliated with the state-controlled umbrella bodies (see Yang, 2007: 636-8). A link between China's religious liberalization, especially the rebuilding of Buddhist and Daoist temples, and the development - indeed exuberant blossoming - of a market economy in the PRC is to be found in a further and connected dimension of government reorientation since the mid-1980s, namely a reversal in attitude to the Chinese Diaspora. Temple rebuilding attracts overseas Chinese investment. There is a new motto for capital acquisition given voice by local government in the PRC: "Build the religious stage to sing the economic opera" (Yang, 2006: 109).

The changing official attitude in the PRC to the overseas Chinese is central for an understanding of both the revival of religion and the development of a capital market. From Liberation (1949) up until the immediate postCultural Revolution period, the Chinese political leadership entertained a thorough and intense suspicion of the overseas Chinese. As the PRC has joined the globalized international market, the economic skills of the overseas Chinese and their capacity to provide investment capital that had earlier led to their stigmatization as "Capitalist Roaders" have been evaluated positively by official forces in the PRC since the 1980s. Those skills and that capacity are now seriously sought by the Chinese market economy. Indeed, since the 1980s there has been much official encouragement of overseas Chinese to invest in the PRC. One means of attracting overseas Chinese investment has been through the temple door. After opening its borders as a consequence of the Deng Xiaoping reforms, the PRC has facilitated visits by significant numbers of overseas Chinese persons who since liberalization have returned to family home sites in the PRC for religious and mortuary rituals (Fan, 2003; Lai, 2003). The program of temple rebuilding mentioned above has coincidentally and conjointly been encouraged enormously through donations made by overseas Chinese individuals and families (Yang and Wei, 2005: 71-2, 86; Lang, Chan and Ragvald, 2005: 157-9). In this way, the erstwhile "Capitalist Roaders" are led to occupy an important place in the course of Chinese economic development (Maddison, 2007: 172-3; Redding, 1993: 231ff.). Indeed, up to the mid-1990s overseas Chinese investors from Hong Kong, Taiwan and Singapore contributed 75 percent of foreign capital to China, and if other overseas Chinese are included the figure goes up to 85 percent, amounting to approximately US $\$ 200$ billion (Hamilton, 2006; Redding, 1995; Sen, 2001: 3). 


\section{Capitalism, Ghina and Max Weber}

It is not simply the magnitude of growth and strength of China's market economy that is so impressive, but also that it erupted against all expectations. It could be argued, of course, that in effectively abandoning socialism, embracing the market and joining capitalist globalization, China's economic growth was inevitable. The limitations of this argument can partly be seen in India's failure to enjoy Chinese levels of economic expansion. It is important to notice, as mentioned above, that during the nineteenth and twentieth century mercantile and financial dynasties were formed within overseas Chinese communities, demonstrating the way in which market opportunities could be realized by persons who adhered to Chinese religions. Nevertheless, in an argument that continues to hold the attention of many sociologists, Max Weber insisted that traditional Chinese religions and the familial commitments associated with them are antithetical to the development of capitalism (Weber, 1964). However, in the face of recent Chinese economic success in both overseas Chinese populations and in the post-1978 PRC, the task must be to explain afresh how Chinese religion and associated family structure might be related to capitalist development.

Weber's characterization of Chinese religion in The Religion of China is to demonstrate the cultural basis of a failure in Imperial China to develop rational or modern industrial capitalism. Weber holds that traditional Chinese values in the form of Confucianism promoted an orientation of talent to state service, to scholarly pursuits that tended to preserve tradition and at the same time to dissuade thinkers from innovation. Confucianism, according to Weber, generates a rationalism that leads persons to adjust to the world rather than encouraging them to change it (Weber, 1964: 248). Daoism, Weber says, promotes an orientation to simplicity in life and harmony with nature. Both of these philosophies or religions are held to discourage capitalistic accumulation and profit seeking. While this broad characterization of Chinese traditional values is more or less descriptively accurate for the period covered by Weber's study, it is quite a different matter to claim that these values were causally implicated in the failure to develop industrial capitalism in Imperial China. Indeed, it is likely that the key inhibiting constraints on Chinese economic development were not cultural. John Hall, for instance, has shown that at crucial times in its long history the imperial Chinese state chose to limit capitalism even as it developed for political reasons (Hall, 1986: 33-57). In more directly addressing Weber's concern regarding the absence in China of the development of industrial capitalism, Mark Elvin (1973: 286-315, 1983) argues that a failure to continue an historically established pattern of innovation necessary for industrialization, which occurred around 1820 
through an insufficiency of demand - what he calls a "high-level equilibrium trap" - inhibited capitalist industrialization in China.

Evidence of both political and economic structural limitations challenge the adequacy of Weber's argument that "rational entrepreneurial capitalism...has been handicapped [in China]... by the lack of a particular mentality" (Weber, 1964: 104). It is not, however, the purpose here to claim that consideration of Confucianism and Daoism is irrelevant to an understanding of economic processes and especially entrepreneurial activity in Chinese cultural areas. But it is important to recognize, contrary to Weber's approach, that the social consequences of culture, and values in particular, are not internal to the culture or values themselves but are contextually effective. Therefore, the relationship between any given value set and economic outcomes for those holding them may vary with changing opportunities and constraints. While Weber attributes Chinese petty bourgeois hoarding to Confucian notions of thrift, for instance, there is no way of knowing whether his theory-laden proposition implies a spurious relationship without first paying attention to the constraints on opportunities for consumption or investment, which Weber fails to do (Weber, 1964: 245).

Weber's inclination to treat institutions in terms of what he sees as the values inherent in them has led to serious misunderstanding concerning the function of key institutions, including the family. In the Protestant Ethic, for instance, Weber writes that Protestant vocation or calling generates emotional detachment and depersonalizes family relations, thus early modern European entrepreneurs are presented as individuals free of family ties and traditional obligations. This perspective on the family is more forcefully stated in his later studies, especially in The Religion of China (Weber, 1964: 237, 240-1, 244), where it is argued that family and community are sources of traditional constraint that inhibit the capitalist ethos of profit making for its own sake as a result of religious values. This argument is seriously mistaken, however, both for Western capitalism and Chinese capitalism. Before considering Chinese religion and capitalism, it is necessary to say something about the family in capitalist development. This is because the motor of economic growth is familial capitalism rather than socially isolated individuals imbued with self-possessed acquisitiveness in both Europe and in the Chinese diaspora from the nineteenth century.

\section{Family as a Resource for Capitalist Development}

The unit of enterprise and the major proximate sources of commercial and business attainment in early modern Europe was not the individual entrepreneur free of family responsibility and commitment, but rather individuals who were economically enriched by kinship networks and marital alliances who thereby 
had immediate access to reputation, credit and uniquely reliable associates (Grassby, 2000). The pattern of European familial capitalism persisted into the nineteenth century (Farrell, 1993; Scranton, 1983) and continued even to the twentieth century, even though by this time national markets for long-term investment were functioning (Postan, 1935: 5-6) thus rendering family credit less important. Writing in the early 1970s, Maurice Zeitlin indicated that in spite of the widespread belief concerning managerial control, the majority of firms in the United States, for instance, continued at that time to be subject to family control and that a large number of the financial institutions that controlled firms which were not directly owned by families were themselves family owned and controlled (Zeitlin, 1974). A more recent study suggests that the incidence of family ownership in the United States may be as high as 80 percent and possibly rising (La Porta, Lopez-de-Silanes and Shleifer 1999; see also Church, 1993).

This brief excursion into Western familial capitalism has the purpose of suggesting that examination of the role of the Chinese family in capitalist enterprise, which a number of studies of both overseas and mainland Chinese business have focused upon (Redding, 1993; Whyte, 1996), is not to highlight an exceptional Chinese contribution to a course of capitalist development but to indicate a neglected but significant aspect of the sociology of capitalism in general. The resources appropriate to capitalistic market production and exchange include financial credit, business information and know-how, reputation for reliability, able associates, trustworthy and low-cost workers and translocal networks. Strong kinship and marital alliances supply these resources in abundance.

Indeed, the significance of the family for economic activity is demonstrated in consideration of employment costs. Economic theories understand labor costs in terms of supply and demand for skills and effort capacities. Quality labor, though, is not simply at the top end of these latter factors but imbued with what John Stuart Mill calls "moral qualities" (Mill, 1940: 110-11). Quality labor, then, can be trusted to work at a high level of efficiency with relatively little supervision whatever its skill or effort capacity. The preparedness of employers to pay above the market rate for workers with these moral qualities is addressed by efficiency wage theory. Family labor, though, simply reverses efficiency wage theory because quality labor is not only efficiently selected through family relations but in family enterprises is frequently paid well below market rates without risking labor turnover, sabotage or shirking. The role of wives working for low or no wages in family firms as business managers or accountants is well known in the West and has recently been demonstrated for family enterprises in the PRC's private sector (Goodman, 2004, 2007; Tsai, 2007: 112-14). This is not to say that inefficiency and nepotism cannot 
occur in family firms (see Redding, 1993: 133-4), but that familial capitalism is not necessarily nonrational, as Weber maintains. Indeed, the application of transaction cost analysis and agency contract theory to family enterprises identifies the aspects of and conditions under which familial capitalism may operate at high levels of market rationality (Pollak, 1985; Steier, 2003).

Chinese families, because they are constituted by transgenerational and lateral networks, are particularly adept at providing the resources for or means of capitalistic agency (Goody, 1996: 151-61; Whyte, 1996: 9-13). Differences between Chinese and Western families in business derive from cultural differences - much is made, for instance, of the Confucian basis of Chinese family structure and practices - but there are also highly salient contingent differences. Gordon Redding, for instance, notes:

The environments in which [overseas Chinese business families] are accustomed to operate have not been notable for their hospitality to business enterprises or to Chinese entrepreneurs. Such entrepreneurs have developed a well-justified wariness in the face of officialdom and a well-honed set of defensive weapons to ensure their survival in an uncertain world. (Redding, 1993: 4)

These learned characteristics are particularly useful when operating within the orbit of the capricious administration of the PRC. While familial capitalism is not necessarily the only factor in the development of post-1978 Chinese market capitalism, it is an important one (Whyte, 1996: 9).

\section{Action: Opportunity Structures and Resources}

As indicated above, Chinese families are an efficient basis of the provision of means for engaging in capitalist activity by reducing the transaction costs of credit and finance and by lowering the agency costs of management, administration and labor. It will be shown here that Chinese religion is particularly important in effectively increasing the opportunities for applying those means in money making. But this requires a very different approach than Weber's to both religion and action.

The close fit between Weber's sociology of religion and his theory of action is readily located in The Protestant Ethic, for instance: Weber approaches religion by identifying the values implicit in religious doctrine as a primary source in the social actor's construction of meaning which in turn is generative of individual motivation or the orientation of action. But the understanding of action in terms of values as the basis of motive raises a number of problems, not the least of which are that effective values are more likely to be the 
outcomes of actions rather than their antecedents and motives are largely inaccessible and frequently innumerable for any given action (Barbalet, 2009). Much more important for understanding action are two factors which Weber tends to neglect. While he notes in the General Economic History that "rational capitalism... is organized with a view to market opportunities" (Weber, 1981: 334), Weber tends to have very little to say about structures of opportunities for action (Barbalet, 2008: 218-19, 221) and he also tends to ignore the means required for the achievement of opportunities (Barbalet, 2008: 123-5). If we think of capitalism in terms of opportunities for money making through market exchanges and the particular resources required to take advantage of or to mobilize for those opportunities, then a general form of motivation can be simply assumed and individual motives cease to be of theoretical interest in understanding economic action. If we think of action in terms of opportunities and resources or means then the family, for instance, can be seen as one source of the means required for market exchanges as indicated above and perception of opportunities can be treated as part of a cultural-cognitive apparatus within which religion may play a role.

The apprehension of novel opportunities for profit making - through the discovery of a market niche, for instance, or a new way of deploying existing resources - is widely recognized as fundamental for market success under capitalist conditions. The concept of opportunity structure therefore addresses the question of the potential for new profit generation and the expansion of the market and economic activity. The significance of opportunity structures is understood in practice by all economic actors. However, theoretical discussion of opportunity has been marred by naturalistic and individualistic assumptions. For instance, in his important statement of the theory of the entrepreneur, Joseph Schumpeter regards opportunities or what he calls "possibilities" as something that are "offered by the surrounding world" and are simply "always present" (Schumpeter, 2008: 79, 88). Schumpeter's supposition that there is no need for a mechanism to generate or realize manifest opportunities from latent "possibilities" is a reflection of his conceptualization of entrepreneurship in terms of individual will and motivation (Schumpeter, 2008: 93-4). While more recent studies have focused on the entrepreneur's characteristically astute grasp of opportunities, their theoretical framework continues to assume that individual mental processes of cognition are sufficient bases of explanation (Mitchell et al., 2002; Shane, 2004). The approach proposed here, on the other hand, places the perception of opportunities not in individual cognitive psychological processes but in cultural apparatuses, including religious frameworks.

While opportunities may be latent in existing arrangements, as Schumpeter holds, opportunities are necessarily prospective - not material - realities and 
become manifest only when they are taken. Opportunity structures therefore only exist as hypotheses or as constructed or discovered possibilities dependent on a particular conjectural perception. Like all perception, the involvement of anticipation and therefore emotion and imagination are central to the formation of opportunity structures, including those for profit making. Religion may play a role here if religion is part of a cultural apparatus that contributes to the notional location or formation of opportunities for profit making. Whether Protestantism, for instance, can be part of such a cultural apparatus must be a matter for empirical investigation. Because religious dissenters, as critics of an established order, may possess novel cognitive orientations or capacities, it is possible that if they are business orientated they could perceive opportunities for profit making that may not otherwise be visible. The difference between this argument and Weber's is large. It is not that Protestantism leads to a capitalistic ethic but that should Protestants be capitalistically involved, then their religion, not as a set of values but as a culturally provided cognitive framework, may generate a perception of opportunity for profit through affective and imaginative appraisal of future prospects irrespective of whatever motive may direct them to profit making.

Weber implicitly and unintentionally raises the question of opportunity in a way compatible with the manner it is set out here. Toward the end of The Religion of China he says enigmatically in the context of his preceding remarks that "The Chinese in all probability would be quite capable, probably more capable than the Japanese, of assimilating capitalism which has technically and economically been fully developed in the modern cultural area" (Weber, 1964: 248). How they might achieve this Weber does not say, apart from a suggestion that cultural osmosis may be the mechanism - he refers to Canton (now Guangzhou) as one place it has happened because of the large numbers of foreigners there (Weber, 1964: 242). It must be noted, though, that in a slightly later work Weber claims that the Japanese are more likely than the Chinese to "take over capitalism as an artefact from the outside" (Weber, 1960: 275). Given Weber's insistence on the incongruity of the values of Chinese religion and capitalism - in which the motive for profit making as an end in itself in market exchanges cannot be deduced from the values of Chinese religious ethics - it is ironic that the cognitive structure of Chinese religions can function as instruments in expanding the horizon of capitalistic opportunities, as indicated below.

\section{Chinese Religion and Expanding Opportunity Structures}

It was mentioned above that Chinese religions cohabit within a polytheistic culture of nonexclusivity. It is feasible to suppose that this nonexclusivity has 
played a role in the advancement of China's post-1978 market economy insofar as the mindset of religious nonexclusivity is part of a cultural apparatus which, in the context of market exchanges, encourages the perception and apprehension of opportunities which may otherwise not be apparent. Because of the lateral elective cognitive mobility available within the Chinese religious universe, which is an aspect of religious nonexclusivity, there is an increased likelihood of a sharpened awareness of an expanding range of possible opportunities in any given situation. But within the lattice of Chinese religious nonexclusivity, the different religions do not equally play a role in encouraging an expanding appreciation of market opportunities. Therefore, it is necessary to give consideration to the different capacities of Buddhism, Confucianism and Daoism to contribute to the likely apprehension of market opportunities.

Chinese Buddhism comprises a number of different "schools" but is unified in being "this worldly" (Mahayana) rather than "other-worldly" (Theravada) in its concerns (Liu, 2008: 218-9). Chinese Buddhist acceptance of performance of mundane activities in achieving nonattachment or nonselfhood (the absence of enduring identity) in renunciation of the world and profit seeking within it contributes to a cognitive apparatus that limits rather than expands the optional set within an opportunity structure. The general and therefore potentially transferable ethical prescriptions of Buddhism similarly offer no encouragement that it might cognitively support an expansive opportunity structure. Buddhist ethics assume the impossibility through moral regulation of improvement of a social order comprising persons with human desires and interests. The affective or emotional direction of Buddhism, therefore, is disengagement from and aversion to this-worldly economic action.

Confucianism, in emphasizing a "middle way" (zhong yong) approach to life and conduct, encourages neutrality, stability and avoiding extreme positions. This has the effect of confining the appreciation of opportunities to a limited range of prospects and stabilizing rather than radically expanding the optional set within an opportunity structure. Because Confucianism is restricted to precedent and has a this-worldly orientation - it both faces the past and is realist - it tends to be restrictive of imagination. At the same time, however, the Confucian understanding of fate does include a significant agentic element: persons establish their own fate by planning ahead, applying their best abilities and taking responsibility for their own actions. According to Confucian teaching, the controlling capacity of fate is not at the level of the selection and execution of a course of action but in whether such actions might succeed or fail (Yang, 1961: 229, 272-3). Thus fate, rather than another human agent, is responsible for the success or failure of a given person's action. On balance, then, and especially relative to Buddhism, Confucianism 
tends to cognitively expand rather than contract the optional set of any given opportunity structure.

The presentation of Daoism in Weber's Religion of China emphasizes what he sees as three essential qualities: its mysticism (Weber, 1964: 180-8), its focus on macrobiotics and immortality (Weber, 1964: 191, 204) and its traditionalism - "more traditionalist than orthodox Confucianism" predicated on the use of magical techniques (Weber, 1964: 205). In his account, Weber confuses and conflates what were earlier in this chapter distinguished as contemplative, purposive and Hsien Daoisms, rendering his globalizing assessment unsustainable. Weber's claim that the Laozi or Daode jing contains an exposition of "contemplative mysticism" (Weber, 1964: 186) reflects what has been described as an antagonistic Confucian interpretation (Hansen, 1992: 7) widely accepted by the Christian missionaries who wrote many of the sources Weber drew upon. Indeed, one scholarly assessment is that the leading Daoist ideas are "more intellectual than mystical" (Granet, quoted in Creel, 1970: 15), although there is no consensus about this in the literature. While some scholars insist on the mystical nature of Daode jing (Schwartz, 1985) others see it as an antimystical and naturalistic or protoscientific work (Needham, 1956; Moeller, 2006; see also Lau, 1963: xxxviii-xli). The principle text of Daoism, Daodejing, while appearing to some as a set of mystical poems is at the same time readily seen as a handbook of statecraft, with a purpose of political counsel and kingly advice anticipating Machiavelli's The Prince. Indeed, the politically instrumental orientation of the text is demonstrated throughout a third-century commentary by Wang Bi (1999), a work which continues to inform the Chinese understanding of the Daode jing. Neither is it possible to show that Daode jing or Zhuangzi advocate magical means or are necessarily traditionalist. Traditional thought and practice, rather, are vulnerable to a key deconstructive tendency within purposive Daoism (Needham, 1956: 33-164). These are the inherent attributes of Daoism that positively encourage nonexclusivity and an experimental expansion of the optional set within any given opportunity structure. These latter are achieved through development and promotion of the concept and practice of what might be described as "paradoxical integration."

Paradoxical integration entails that opposite elements of a thing are interdependent and mutually supportive, best represented in the relationship between yin and yang. The opposition between elements of a paradoxical integration is not contradictory in the Western sense that one element eliminates the other, but rather is held to give rise to generative relationships of a number of types between opposites. Daode jing is a veritable handbook of paradoxical integration, with more than forty percent of the text occupied with examples and expositions of paradoxical integration. Thus, according to the Daode jing, 
opposites are held to be mutually productive of each other, for instance, that in order to achieve a purpose its opposite must be attempted, that a thing seems to be quite other than it is, and so on (Ames and Hall, 2003: 80, 133, 140-41). The Daoist notions of strength in weakness and advantage in threat or danger generate perceptions of opportunities in market engagements which might otherwise not materialize.

Daoism has been relatively neglected in considerations of Chinese religion, probably because it is institutionally weaker than Buddhism. The diffuse nature of Chinese religion, however, means that its importance and influence cannot be measured by the number of its supporters but by the pervasiveness of its concepts. The conventional approach of associating overseas Chinese business success with Confucian principles, for example, is based on the assumption that Chinese family dynamics are Confucian (Haley, Haley and Tan, 2004; Haley, Tan and Haley, 1998; Redding, 1993; Whyte, 1996). There is more than an element of truth in this supposition, even though it neglects the importance of Daoist ideas concerning family and marital relations. These ideas round out and strengthen Confucian precepts associated with the durability of Chinese families, especially in terms of Daoist encouragement of discovering "the natural" course in relationships and in emphasizing the importance of the feminine and therefore encouraging a certain type of regard for women.

\section{Conclusion}

Chinese religion and China's market economy can be seen as mutually supportive in a number of ways. First, the revival of Buddhism and Daoism in post-1978 China has been a conduit for investment in the market economy of the PRC from the Chinese diaspora. Second, the success of overseas Chinese since the nineteenth century in capitalist ventures in East and Southeast Asia suggests a positive relationship between market rationality on the one hand and Chinese religion and family on the other that raises questions concerning the received Weberian perspective. Third, an approach to religion as part of a cultural apparatus instrumental in the apprehension of opportunity structures for capitalistic activity is outlined in the chapter, which indicates the significance of Chinese religious nonexclusivity in general and Daoism in particular for successful market engagements through opportunity perceptiveness.

Throughout the chapter, the significance of the relationship between the political state and religion has been indicated. The long historical relationship in China between the state and religion has been characterized as one of state regulation of religion moderated by brief interspersed episodes of patronage or prohibition. Regulatory relations have frequently included co-option of religious forces for state purposes. This is demonstrated in 
the present post-1978 period by the state sponsored but privately funded program of temple restoration that is a conduit for capital investment in the PRC by overseas Chinese.

In contrasting Chinese and Western religion it was shown above that a Chinese term for religion, zong jiao, was invented in the nineteenth century because none had previously existed. Religion in the modern Western sense of a belief system supported by doctrine, organization and leadership has simply been absent in Chinese society. Chinese traditions of temples, ritual practices and ceremonial practitioners relate to local communities and the rhythms of their needs in multifunctional spaces in which liturgy has little salience and performative elements prevail. In this context the introduction of a concept of "religion" as a system of belief carried by a congregation organized by a professional clergy challenges traditional community rituals and practices by separating out "superstition" and also "culture" from "religion" to the detriment of the traditional forms (Ashiwa and Wank, 2009: 9-12; Dean, 2009: 188-91). Thus, the nineteenth-century invention of Chinese religion, which Weber draw upon and contributed to, in this sense was a further instrument of state regulation in the service of modernization.

An aspect of Chinese religion, to use the term on notice, which has remained more or less outside the reach of state regulation and control, is referred to above as its "diffused" aspects. This includes the conceptual and dispositional elements of a cultural legacy that exist in language and idiom. This aspect of Chinese religion is signal in the acumen of Chinese business in generating an expansive opportunity structure necessary for market engagement, as indicated in discussion above.

\section{References}

Ames, Roger T. and David L. Hall. 2003. Daodejing: A Philosophical Translation. New York: Ballantine Books.

Ashiwa, Yoshika and David L. Wank. 2009. "Making Religion, Making the State in Modern China." In Yoshiko Ashiwa and David L. Wank (eds), Making Religion, Making the State: The Politics of Religion in Modern China, 1-21. Stanford, CA: Stanford University Press.

Barbalet, Jack. 2008. Weber, Passion and Profits: "The Protestant Ethic and the Spirit of Capitalism" in Context. Cambridge: Cambridge University Press. . 2009. "Action Theoretic Foundations of Economic Sociology." Wirtschaftssoziologie. Kölner Zeitschrift für Soziologie und Sozialpsychologie, Sonderheft 49: 143-57.

. 2011. "Market Relations as Wuwei: Traditional Concepts in Analysis of China's Post-1978 Economy." Asian Studies Review 35.3: 335-54.

Brook, Timothy. 2009. "The Politics of Religion: Late-Imperial Origins of the Regulatory State." In Yoshiko Ashiwa and David L. Wank (eds), Making Religion, Making the State: The Politics of Religion in Modern China, 22-42. Stanford, CA: Stanford University Press.

Chien, Szuma. 1979. Selections from Records of the Historian (trans. Yang Hsien-yi and Gladys Yang). Peking: Foreign Languages Press. 
Church, Roy. 1993. "The Family Firm in Industrial Capitalism: International Perspectives on Hypothesis and History." Business History 35.4: 17-43.

Creel, Herrlee G. 1977. "What is Taoism?" In Herrlee G. Creel, What is Taoism? And Other Studies in Chinese Cultural History, 1-24. Chicago: University of Chicago Press.

Dean, Kenneth. 2009. "Further Partings of the Way: The Chinese State and Daoist Ritual Traditions in Contemporary China." In Yoshiko Ashiwa and David L. Wank (eds), Making Religion, Making the State: The Politics of Religion in Modern China, 179-210. Stanford, CA: Stanford University Press.

Dunn, Emily C. 2009. "CCult,' Church and the CCP: Introducing Eastern Lighting." Modern China 35.1: 96-119.

Elvin, Mark. 1973. The Patterns of the Chinese Past. Stanford, CA: Stanford University Press. . 1983. "Why China Failed to Create an Endogenous Industrial Capitalism." Theory and Society 13.3: 379-91.

Fan, Lizhu. 2003. "Popular Religion in Contemporary China." Social Compass 50.4: 449-57.

Farrell, Betty G. 1993. Elite Families: Class and Power in Nineteenth-Century Boston. Albany, NY: SUNY Press.

Gerlach, Christian. 2005. "Wu-Wei in Europe. A Study of Eurasian Economic Thought." Working Paper No. 12/05. London: Department of Economic History, London School of Economics.

Goodman, David S. 2004. "Why Women Count: Chinese Women and the Leadership of Reform." In Anne Elizabeth Mclaren (ed.), Chinese Women: Living and Working, 19-41. London: Edward Elgar.

2007. "Narratives of Change: Culture and Local Economic Development." In Anne McLaren (ed.), The Chinese Economy in the 21st Century: Enterprise and Business Behaviour, 175-201. London: RoutledgeCurzon.

Goody, Jack. 1996. The East in the West. Cambridge: Cambridge University Press.

Goossaert, Vincent. 2003. "Le Destin de la Religion Chinoise au 20ème Siècle." Social Compass 50.4: 429-40.

Granet, Marcel. 1975. The Religion of the Chinese People. Oxford: Basil Blackwell.

Grassby, Richard. 2000. Kinship and Capitalism: Marriage, Family and Business in the EnglishSpeaking World, 1580-1740. Cambridge: Cambridge University Press.

Haley, George T., Usha C. V. Haley and Chin Tiong Tan. 2004. The Chinese Tao of Business: The Logic of Successful Business Strategy. New York: Wiley. . 1998. New Asian Emperors: The Overseas Chinese. Oxford: Butterworth Heinemann.

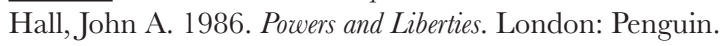

Hamilton, Gary G. 2006. Commerce and Capitalism in Chinese Societies. London: Routledge.

Hansen, Chad. 2000. A Daoist Theory of Chinese Thought: A Philosophical Interpretation. New York: Oxford University Press.

Huang, Jianbo and Fenggang Yang. 2005. "The Cross Faces the Loudspeakers: A Village Church Perseveres under State Power.” In Fenggang Yang and Joseph B. Tamney (eds), State, Market, and Religions in Chinese Societies, 41-62. Leiden: Brill.

Hudson, Geoffrey Francis. 1961. Europe and China: A Survey of their Relations from the Earliest Times to 1800. Boston, MA: Beacon Press.

Lai, Chi-Tim. 2003. "Daoism in China Today: 1980-2002." China Quarterly 174: 413-27.

Lang, Graeme, Chan, Selina and Ragvald, Lars. 2005. "Temples and the Religious Economy.” In Fenggang Yang and Joseph B. Tamney (eds), State, Market, and Religions in Chinese Societies, 149-80. Leiden: Brill.

La Porta, Rafael, Florencio Lopez-de-Silanes and Andrei Shleifer. 1999. "Corporate Ownership around the World." Fournal of Finance 54.2: 471-517. 
Lau, D. C. 1963. "Introduction.” In Lao Tzu, Tao Te Ching (trans. D. G. Lau), vii-xlv. London: Penguin Books.

Liu, JeeLoo. 2008. An Introduction to Chinese Philosophy: From Ancient Philosophy to Chinese Buddhism. Oxford: Blackwell.

Maddison, Angus. 2007. Contours of the World Economy. Oxford: Oxford University Press.

Mill, John Stuart. 1940. Principles of Political Economy (ed. J. W. Ashley). London: Longmans.

Mitchell, Ronald K., Lowell Busenitz, Theresa Lant, Patricia P. McDougall, Eric A. Morse and J. Brock Smith. 2002. "Toward a Theory of Entrepreneurial Cognition." Entrepreneurship Theory and Practice 27.2: 93-104.

Moeller, Hans-Georg. 2006. The Philosophy of the Daodejing. New York: Columbia University Press.

Needham, Joseph. 1956. Science and Civilization in China: Volume 2, History of Scientific Thought. Cambridge: Cambridge University Press.

Nivison, David S. 1959. "Introduction." In David S. Nivison and Arthur F. Wright (eds), Confucianism in Action, 3-24. Stanford, CA: Stanford University Press.

Ownby, David. 2004. "The Falun Gong: A New Religious Movement in Post-Mao China." In James R. Lewis and Jesper Aagaard Petersen (eds), Controversial New Religions, 195214. New York: Oxford University Press.

Pollak, Robert A. 1985. "A Transaction Cost Approach to Families and Households." Fournal of Economic Literature 23.2: 581-608.

Postan, M. M. 1935. "Recent Trends in the Accumulation of Capital." Economic History Review 6.1: 1-12.

Redding, S. Gordon. 1993. The Spirit of Chinese Capitalism. Berlin: Walter de Gruyer. . 1995. "Overseas Chinese Networks: Understanding the Enigma." Long Range Planning 28.1: 6-19.

Reichwein, Adolf. 1968. China and Europe: Intellectual and Artistic Contacts in the Eighteenth Century. New York: Barnes and Noble.

Schumpeter, Joseph. A. 2008. The Theory of Economic Development: An Inquiry into Profits, Capital, Credit, Interest, and the Business Cycle. New Brunswick, NJ: Transaction Publishers.

Schwartz, Benjamin I. 1985. The World of Thought in Ancient China. Cambridge, MA: Harvard University Press.

Scranton, Philip. 1983. Proprietary Capitalism: The Textile Manufacture at Philadelphia 18001895. Cambridge: Cambridge University Press.

Sen, Gautam. 2001. Post-Reform China and the International Economy: Economic Change and Liberalisation under Sovereign Control. London: The Global Site.

Shane, Scott Andrew. 2004. A General Theory of Entrepreneurship: The Individual-Opportunity Nexus. London: Edward Elgar.

Steier, Lloyd. 2003. "Variants of Agency Contracts in Family-financed Ventures as a Continuum of Familial and Market Rationalities." Journal of Business Venturing 18.5: 597-618.

Sun, Anna Xiao Dong. 2005. "The Fate of Confucianism as Religion in Socialist China: Controversies and Paradoxes." In Fenggang Yang and Joseph B. Tamney (eds), State, Market, and Religions in Chinese Societies, 229-53. Leiden: Brill.

Tong, James W. 2009. Revenge of the Forbidden City: The Suppression of the Falungong in China, 1999-2005. New York: Oxford University Press.

Tsai, Kellee S. 2007. Capitalism without Democracy: The Private Sector in Contemporary China. Ithaca, NY: Cornell University Press. 
Wang, Bi. 1999. The Classic of the Way and Virtue: A New Translation of the Tao-te ching as Interpreted by Wang Bi (trans. Richard John Lynn). New York: Columbia University Press.

Weber, Max. 1960. The Religion of India: The Sociology of Hinduism and Buddhism (trans. and ed. by Hans H. Gerth and Don Martindale). New York: The Free Press.

1964. The Religion of China: Confucianism and Taoism (trans. and ed. Hans H. Gerth, with an introduction by C. K. Yang). New York: The Free Press.

. 1981. General Economic History (trans. by Frank Knight). New Brunswick, NJ:Transaction Books.

. 1991. The Protestant Ethic and the Spirit of Capitalism (trans. Talcott Parsons). London: HarperCollins.

Whyte, Martin King. 1996. "The Chinese Family and Economic Development: Obstacle or Engine?" Economic Development and Cultural Change 45.1: 1-30.

Yang, Ching Kun. 1961. Religion in Chinese Society: A Study of Contemporary Social Functions of Religion and Some of their Historical Factors. Berkeley, CA: University of California Press.

Yang, Der-Ruey. 2005. "The Changing Economy of Temple Daoism in Shanghai." In Fenggang Yang and Joseph B. Tamney (eds), State, Market, and Religions in Chinese Societies, 113-48. Leiden: Brill.

Yang, Fenggang. 2006. "The Red, Black and Gray Markets of Religion in China." Sociological Quarterly 47: 93-122.

. 2007. "Oligopoly Dynamics: Official Religions in China." In James A. Beckford and N. J. Demerath (eds), The SAGE Handbook of the Sociology of Religion, 635-53. London: SAGE.

Yang, Fenggang and Dedong Wei. 2005. "The Bailin Buddhist Temple: Thriving under Communism." In Fenggang Yang and Joseph B. Tamney (eds), State, Market, and Religions in Chinese Societies, 63-86. Leiden: Brill.

Yijie, Tang. 2007. "Constructing Chinese Philosophy in Sino-European Cultural Exchange." In Karyn I. Lai (ed.), New Interdisciplinary Perspectives in Chinese Philosophy, 33-42. Oxford: Blackwell.

Zeitlin, Maurice. 1974. "Corporate Ownership and Control: The Large Corporation and the Capitalist Class." American Fournal of Sociology 79.5: 1073-1119. 
Chapter Title: Front Matter

Book Title: Religion and the State

Book Subtitle: A Comparative Sociology

Book Editor(s): Jack Barbalet, Adam Possamai, Bryan S. Turner

Published by: Anthem Press. (2011)

Stable URL: http://www.jstor.org/stable/j.ctt1wn0r14.1

JSTOR is a not-for-profit service that helps scholars, researchers, and students discover, use, and build upon a wide range of content in a trusted digital archive. We use information technology and tools to increase productivity and facilitate new forms of scholarship. For more information about JSTOR, please contact support@jstor.org.

Your use of the JSTOR archive indicates your acceptance of the Terms \& Conditions of Use, available at http://about.jstor.org/terms

This book is licensed under a Creative Commons Attribution 4.0 International. To view a copy of this license, visit http://creativecommons.org/licenses/by/4.0/. Funding is provided by Knowledge Unlatched. 


\section{Chapter Title: Table of Contents}

Book Title: Religion and the State

Book Subtitle: A Comparative Sociology

Book Editor(s): Jack Barbalet, Adam Possamai, Bryan S. Turner

Published by: Anthem Press. (2011)

Stable URL: http://www.jstor.org/stable/j.ctt1wn0r14.2

JSTOR is a not-for-profit service that helps scholars, researchers, and students discover, use, and build upon a wide range of content in a trusted digital archive. We use information technology and tools to increase productivity and facilitate new forms of scholarship. For more information about JSTOR, please contact support@jstor.org.

Your use of the JSTOR archive indicates your acceptance of the Terms \& Conditions of Use, available at http://about.jstor.org/terms

This book is licensed under a Creative Commons Attribution 4.0 International. To view a copy of this license, visit http://creativecommons.org/licenses/by/4.0/. Funding is provided by Knowledge Unlatched. 